\title{
PROPORSI DAN KOMPOSISI HASIL TANGKAPAN JARING TIGA LAPIS (TRAMMEL NET) DI PELABUHAN RATU
}

\author{
Hufiadi \\ Peneliti pada Balai Riset Perikanan Laut, Muara Baru-Jakarta \\ Teregristrasi I tanggal: 7 Januari 2008; Diterima setelah perbaikan tanggal: 5 Mei 2008; \\ Disetujui terbit tanggal: 15 Mei 2008
}

\begin{abstract}
ABSTRAK
Nelayan di Pelabuhan Ratu banyak mengoperasikan alat tangkap Jaringan tiga lipat (jatilap) yang memiliki perbedaan ukuran mata jaring, khususnya jaring lapisan dalam (inner net). Hal ini diduga dapat mempengaruhi komposisi hasil tangkapan ikan yang diperoleh berdasarkan pada jatilap yang diujicobakan yaitu dengan cara terjerat, terpuntal, terkantung, dan tersangkut. Ikan yang tertangkap dengan cara terpuntal paling dominan dibandingkan dengan cara lainnya. Jatilap dengan jaring lapisan dalam 1,75" memperoleh total tangkapan 259 ekor $(51,59 \%)$ terdiri atas udang dogol (sasaran tangkapan) 10 ekor dan tangkapan lain (bukan sasaran) 249 ekor. Sementara itu, untuk jaring lapisan dalam 2,0" menangkap udang 9 ekor dan tangkapan lainnya 234 ekor dengan total tangkapan 243 ekor (48,41\%). Ikan yang dominan tertangkap jatilap adalah ikan bilis (Thryssa sp.) $(25,5 \%)$, pepetek (Leiognathus spp) (19,7\%), dan senangin (Polynemus sp.) (16,3\%).
\end{abstract}

KATAKUNCI: jatilap, mata jaring, proporsi, komposisi, Pelabuhan Ratu

\section{PENDAHULUAN}

Salah satu kelompok alat tangkap yang banyak digunakan nelayan, khususnya di Pelabuhan Ratu adalah jaring insang. Kelompok alat tangkap ini umumnya digunakan baik oleh nelayan tradisional maupun nelayan dalam skala usaha yang cukup besar, termasuk ke dalam alat tangkap jaring tiga lapis. Jaring tiga lapis (trammel net) disingkat jatilap (Mahiswara \& Wudianto, 1991; Subani \& Barus 1989).

Jatilap (trammel net) adalah alat tangkap yang terbentuk dari 3 susunan jaring yang dirangkai secara memanjang seperti jaring insang secara umum. Jaring lapisan dalam (inner net) diapit oleh dua lembar jaring lapisan luar (outer net) dengan mata jaring berukuran lebih besar dan berfungsi sebagai bingkai (Purbayanto, 2006). Nelayan jatilap di Pelabuhan Ratu lebih banyak mengoperasikan alat tangkap ini di dasar perairan dengan tujuan utama untuk menangkap udang, namun alat tangkap ini juga efektif manangkap jenis ikan lain.

Alat tangkap yang digunakan oleh nelayan memiliki perbedaan ukuran mata jaring, khususnya jaring lapisan dalam (inner net). Hal ini diduga dapat mempengaruhi komposisi hasil tangkapan yang diperoleh. Secara umum, cara tertangkap ikan dan udang pada alat tangkap jatilap ini dapat secara terjerat (gilled), terpuntal (entangled), tersangkut (snagged), dan terkantung (pocketted) (Purbayanto, et al., 2000 ). Tulisan ini mengidentifikasi komposisi dan proporsi hasil tangkapan jatilap di Teluk Pelabuhan Ratu yang mempunyai ukuran mata jaring lapisan dalam (inner net) yang berbeda, terdiri atas empat pis berukuran 1,75" dan empat pis berukuran 2,0".
Sedangkan ukuran jaring lapisan luar, setiap pisnya berukuran 6,5 " dan panjang setiap pis jaring berukuran $35 \mathrm{~m}$. Hasil tulisan ini diharapkan dapat mengetahui tingkat kemampuan suatu alat tangkap jatilap yang diuji cobakan terhadap proporsi komposisi hasil tangkapan yang diperoleh.

\section{PROPORSI DAN KOMPOSISI HASIL TANGKAPAN JATILAP}

Selama operasi jatilap (3 kali tawur) di Teluk Pelabuhan Ratu diperoleh tangkapan 22 jenis dengan jumlah individu mencapai 502 ekor terdiri atas kelompok udang 37 ekor atau 7,4\% dan kelompok non udang 465 ekor atau 92,6\% (Gambar 1).Secara keseluruhan, jenis tangkapan non udang didominasi oleh ikan bilis (Thryssa sp.) 128 ekor (25,5\%), berikutnya pepetek (Leiognathus spp.) 99 ekor $(19,7 \%)$, dan senangin (Polynemus sp.) 82 ekor $(16,3 \%)$. Sementara itu, hasil tangkapan kelompok udang diwakili oleh udang dogol (Metapenaeus sp.) 19 ekor atau 3,8\% dan udang ronggeng (Squilla mantis) 18 ekor atau 3,6\%. Udang dogol (Metapenaeus sp.) merupakan tujuan utama penangkapan (target catch) alat tangkap jatilap (Subani \& Barus, 1989; SEAFDEC, 1999). Udang ronggeng (Squilla mantis) dari tangkapan jatilap ini bukan merupakan tangkapan utama (non target species).

Perbedaan ukuran jaring lapisan dalam menyebabkan perbedaan proporsi komposisi hasil tangkapan pada setiap ukuran mata jaring. Jaring lapisan dalam 1,75" memperoleh tangkapan udang sebagai tujuan utama penangkapan 10 ekor, 


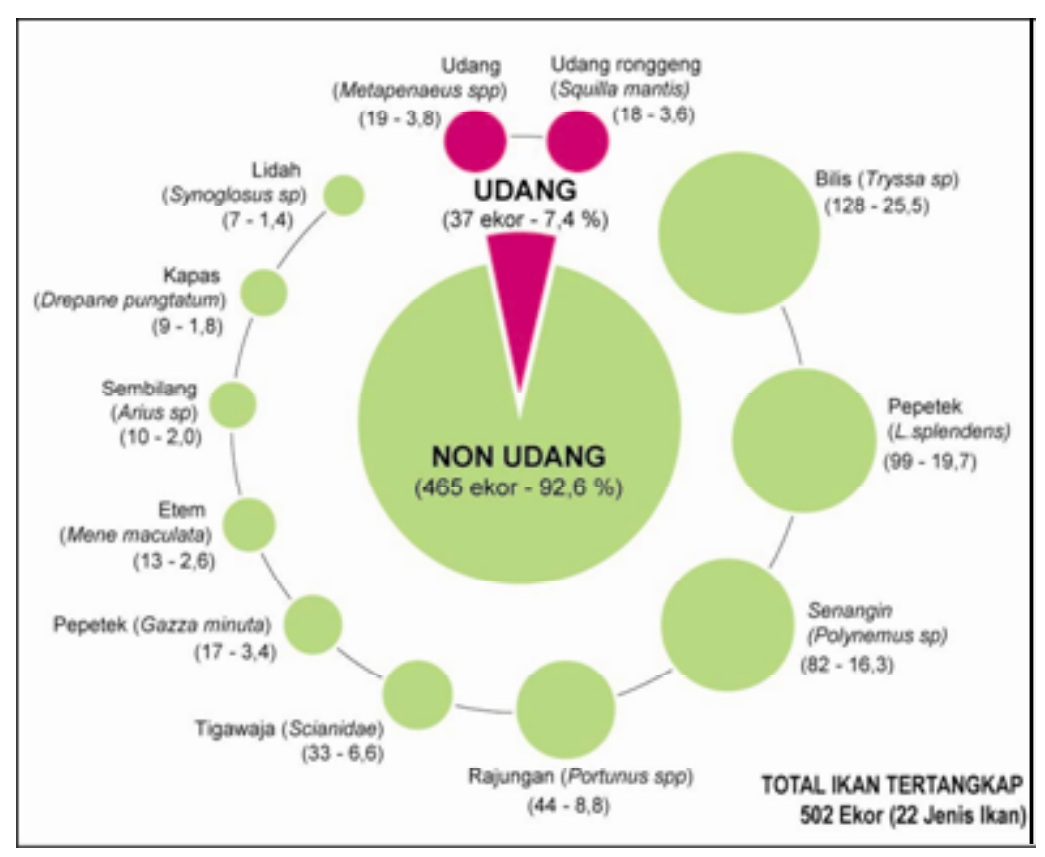

Gambar 1. Proporsi dan komposisi hasil tangkapan jatilap.

tangkapan lainnya (bukan tujuan utama penangkapan) 249 ekor sehingga total tangkapan 259 ekor (51,59\%). Sedangkan untuk jaring lapisan dalam 2,0" menangkap udang 9 ekor dan tangkapan lainnya (non target species) 234 ekor sehingga total tangkapannya 243 ekor $(48,41 \%)$ dan ikan yang paling banyak tertangkap adalah ikan bilis, pepetek, dan senangin (Tabel 1). Sebagai ilustrasi, Pawarti \& Nugroho (1988) mengatakan bahwa pada periode pasca pelarangan trawl di Laut Jawa, hasil tangkapan per trip pada perikanan pepetek didominasi oleh alat tangkap jaring klitik (termasuk trammel net) dan pukat pantai.

Persentase dari ketiga ikan tersebut, yaitu bilis, pepetek, dan senangin mencapai $61,55 \%$ dari total tangkapan, menunjukkan keberadaan ketiga jenis ikan tersebut relatif melimpah. Hal ini dapat disebabkan oleh beberapa hal: Pertama, daerah pengoperasian dilakukan pada daerah pesisir pada kedalaman 10$15 \mathrm{~m}$ dan kedalaman tersebut diduga merupakan daerah ruaya dari ketiga jenis ikan tersebut. Kedua, sifat dari ketiga jenis ikan tersebut merupakan ikan yang memiliki sifat bergerombol (schooling). Hal ini dapat dibuktikan di mana dalam 1 pis jatilap dapat tertangkap 6-10 ekor ikan bilis, pepetek, atau senangin. Khusus untuk ikan pepetek, hasil analisis terhadap data survei periode tahun 1979 dan 1986 di perairan pantai utara Jawa Tengah menunjukkan bahwa pada tahun 1979 pengelompokkan ikan pepetek cenderung pada kedalaman kurang dari 20 $\mathrm{m}$ dan tahun 1986 pengelompokkan cenderung pada kedalaman antara 20-30 m (Pawarti \& Nugroho, 1988). Sebaran ikan pepetek di Laut Jawa cenderung berada pada kedalaman $25 \mathrm{~m}$ dengan kisaran kedalaman 10 -70 m (Pauly, 1977 dalam Pawarti \& Nugroho, 1988). Hal ini menunjukkan bahwa ikan pepetek tersebar dan dapat beradaptasi di berbagai perairan.

Sedangkan udang yang merupakan sasaran tangkapan hanya tertangkap 19 ekor (3,8\%). Berdasarkan pada hasil wawancara bahwa belakangan ini nelayan jatilap Pelabuhan Ratu dan di sekitarnya banyak melakukan operasi penangkapan ke daerah (fishing ground) yang lebih jauh (keluar dari Teluk) di antara ke Ujung Genteng, Cisolok, dan Binuangeun. Hal ini merupakan indikasi bahwa nelayan berupaya merespon perubahan sumber daya udang di perairan Teluk Pelabuhan Ratu yang diduga telah mengalami tekanan yang disebabkan oleh tingginya upaya penangkapan (over capacity). Hal ini ditunjukkan dengan jumlah jatilap (trammel net) yang dioperasikan mengalami peningkatan tajam dari 1.326 unit tahun 1992 menjadi 9.230 unit pada tahun 1993 (Purbayanto, 2006).

Tingginya tangkapan sampingan dibandingkan tangkapan utama (udang) berkaitan erat dengan karakteristik perairan tropis yang bersifat multi spesies di mana pada habitat yang sama hidup beragam spesies, khususnya bagi sumber daya ikan demersal. Daerah penangkapan (fishing ground) jatilap pada umumnya adalah daerah pantai, teluk, dan muara yang mengakibatkan ikan tertangkap dari berbagai jenis yang sebenarnya tujuan utamanya adalah menangkap udang (Ayodhyoa, 1981). 
Tabel 1.

Komposisi, jumlah (n) hasil tangkapan sasaran tangkapan dan bukan sasaran tangkapan pada mata jaring 1,75" dan 2,0"

\begin{tabular}{|c|c|c|c|c|c|c|c|c|c|c|c|c|}
\hline \multirow[b]{2}{*}{ Jenis ikan } & \multicolumn{3}{|c|}{ Setting 1} & \multicolumn{3}{|c|}{ Setting 2} & \multicolumn{3}{|c|}{ Setting 3} & \multicolumn{3}{|c|}{ Setting 1-3 } \\
\hline & $\begin{array}{c}\text { MS } \\
1,75^{\prime \prime}\end{array}$ & $\begin{array}{l}\text { MS } \\
2 "\end{array}$ & Total & $\begin{array}{l}\text { MS } \\
1,75^{\prime \prime}\end{array}$ & $\begin{array}{l}\text { MS } \\
2 "\end{array}$ & Total & $\begin{array}{c}\text { MS } \\
1,75^{\prime \prime}\end{array}$ & $\begin{array}{l}\text { MS } \\
2 "\end{array}$ & Total & $\begin{array}{c}\text { MS } \\
1,75^{\prime \prime}\end{array}$ & $\begin{array}{l}\text { MS } \\
2 "\end{array}$ & Total \\
\hline \multicolumn{13}{|l|}{ Target tangkapan } \\
\hline $\begin{array}{l}\text { Udang } \\
\text { (Metapenaeus spp.) }\end{array}$ & 3 & 5 & 8 & 4 & 4 & 8 & 3 & 0 & 3 & 10 & 9 & 19 \\
\hline Bukan target tangkapan & 87 & 57 & 144 & 131 & 143 & 274 & 31 & 34 & 65 & 249 & 234 & 483 \\
\hline Bilis(Tryssa sp.) & 24 & 15 & 39 & 41 & 36 & 77 & 8 & 4 & 12 & 73 & 55 & 128 \\
\hline $\begin{array}{l}\text { Pepetek } \\
\text { (L. splendens) }\end{array}$ & 44 & 10 & 54 & 13 & 32 & 45 & 0 & 0 & 0 & 57 & 42 & 99 \\
\hline $\begin{array}{l}\text { Senangin } \\
\text { (Polynemus sp.) }\end{array}$ & 10 & 2 & 12 & 31 & 26 & 57 & 5 & 8 & 13 & 46 & 36 & 82 \\
\hline $\begin{array}{l}\text { Rajungan } \\
\text { (Portunus spp.) }\end{array}$ & 3 & 8 & 11 & 6 & 15 & 21 & 5 & 7 & 12 & 14 & 30 & 44 \\
\hline Tigawaja (Scianidae) & 5 & 5 & 10 & 7 & 8 & 15 & 4 & 4 & 8 & 16 & 17 & 33 \\
\hline Lain-lain & 1 & 17 & 18 & 33 & 26 & 59 & 9 & 11 & 20 & 43 & 54 & 97 \\
\hline Jumlah & 90 & 62 & 152 & 135 & 147 & 282 & 34 & 34 & 68 & 259 & 243 & 502 \\
\hline
\end{tabular}

\section{UKURAN HASIL TANGKAPAN}

Sebagai gambaran ukuran contoh yang terukur dari hasil tangkapan jatilap yang dioperasikan, diperoleh pada jaring lapisan dalam 1,75", kisaran ukuran ikan bilis, panjang cagak (fork length) $7-9 \mathrm{~cm}$, lingkar badan (body girth) 5,8-9,0 cm dan bobot (weight) 7,0 sampai $90 \mathrm{~g}$. Untuk udang dogol kisaran panjang karapas 9,5-18 cm dan bobot 9,5-60 g. Sementara itu, pada jaring lapisan dalam 2,0", kisaran ukuran ikan bilis diperoleh fork length $8,7-13,5 \mathrm{~cm}$, body girth 6,0-10 cm, dan weight 8-50 g. Udang yang tertangkap berada pada kisaran panjang karapas $8,0-19,5 \mathrm{~cm}$ dan bobot 10-70 $\mathrm{g}$.

\section{CARA TERTANGKAP HASIL TANGKAPAN}

Berdasarkan pada cara ikan tertangkap, pada jatilap yang diujicobakan secara umum diperoleh ikan tertangkap dengan cara terjerat ( $\mathrm{g}$ illed), terpuntal (entangled), terkantung (pocketted), dan tersangkut (snagged) (Gambar 2).Pola tertangkap hasil tangkapan pada jatilap dapat disebabkan beberapa faktor spesifikasi jaring antara lain desain jatilap (hanging ratio, elastisitas, dan fleksibilitas rentangan jaring, visibilitas jaring, sifat bahan jaring, bentuk, dan tingkah laku ikan) dan morfologi hasil tangkapan (Matsuoka, 1995 dalam Purbayanto et al., 2000; Sparre \& Venema, 1992).

Berdasarkan pada masing-masing tawur, diperoleh tangkapan pada tawur pertama dengan cara terjerat 33 ekor, terpuntal 42 ekor, terkantung 36 ekor, dan tersangkut 41 ekor. Pada tawur kedua diperoleh dengan cara terjerat 63 ekor, terpuntal 119 ekor, terkantung 17 ekor, dan tersangkut 83 ekor. Pada tawur ketiga diperoleh dengan cara terjerat berjumlah 7 ekor, terpuntal 18 ekor, terkantung 16 ekor, dan tersangkut 27 ekor. Tertangkapnya udang dengan cara terkantung dan tersangkut (1 ekor), sedangkan ikan yang dominan tertangkap, yaitu bilis yang didominansi oleh terjerat dan tersangkut. Untuk non ikan (rajungan) dominan tertangkap dengan cara tersangkut (Gambar 3).

Cara tertangkap tangkapan pada jatilap, selain terjerat pada mata jaring bagian jaring lapisan dalam, juga tertangkap secara terpuntal pada mata jaring bagian jaring lapisan dalam dan jaring lapisan luar. Ikan yang tertangkap dengan cara terpuntal diperoleh paling dominan dibandingkan tertangkap dengan cara yang lainnya. Hal ini sesuai dengan cara penangkapan jatilap yang masuk dalam kategori tangle net (memuntal). Ikan-ikan yang telah diidentifikasi mempunyai ukuran operculum girth lebih kecil dan maximum body girth lebih besar dari keliling mata jaring lapisan dalam, juga ikan mempunyai keliling operculum girth lebih besar dari keliling jaring lapisan dalam (inner net), tetapi keliling maximum body girth lebih kecil dari keliling jaring lapisan luar (outer net).

Ikan pepetek, senangin, dan tigawaja (Johnius dussumieri) dominan tertangkap dengan cara terputal karena ketiga jenis ikan tersebut memiliki bentuk badan yang pipih atau lonjong serta dilengkapi dengan sirip punggung dan ekor yang keras sehingga pada saat ikan-ikan tersebut menerobos inner net akan tersangkut atau tersangkut pada saat meronta untuk melepaskan diri. Ikan-ikan tersebut juga cukup banyak tertangkap dengan cara terjerat dan tersangkut. Hal 


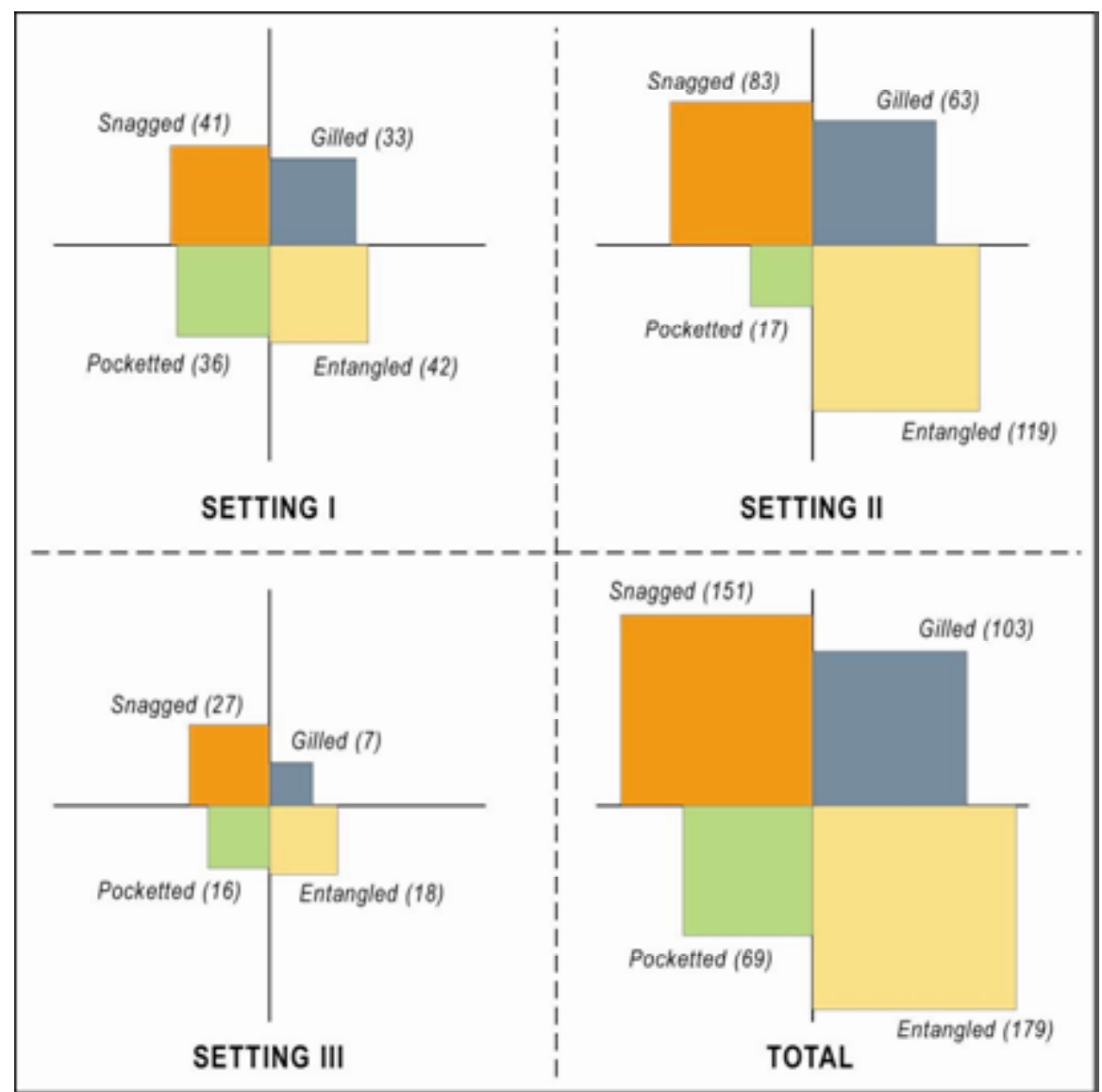

Gambar 2. Cara tertangkap hasil tangkapan pada masing-masing tawur (setting).

ini disebabkan antara lain ukuran operculum girth lebih kecil dan maximum body girth lebih besar dari keliling mata jaring lapisan dalam, juga ikan yang mempunyai keliling operculum girth lebih besar dari keliling jaring lapisan dalam tetapi keliling maximum body girth lebih kecil dari keliling jaring lapisan luar.

Rajungan banyak tertangkap dengan cara tersangkut karena rajungan memiliki cangkang yang keras dan bentuk tidak beraturan serta pada bagian depan mulut terdapat tonjolan yang keras sehingga mudah tersangkut pada mata jaring di bagian mulut. Sedangkan udang dogol sebagian besar tertangkap dengan cara terkantung, hal ini dipengaruhi oleh karapas yang keras dan bentuk badan agak melengkung, sehingga pada saat menerobos jaring lapisan dalam bagian karapas dan kaki akan terjerat mata jaring dan akan terkantung pada jaring lapisan dalam sesuai dengan bentuk badan. 


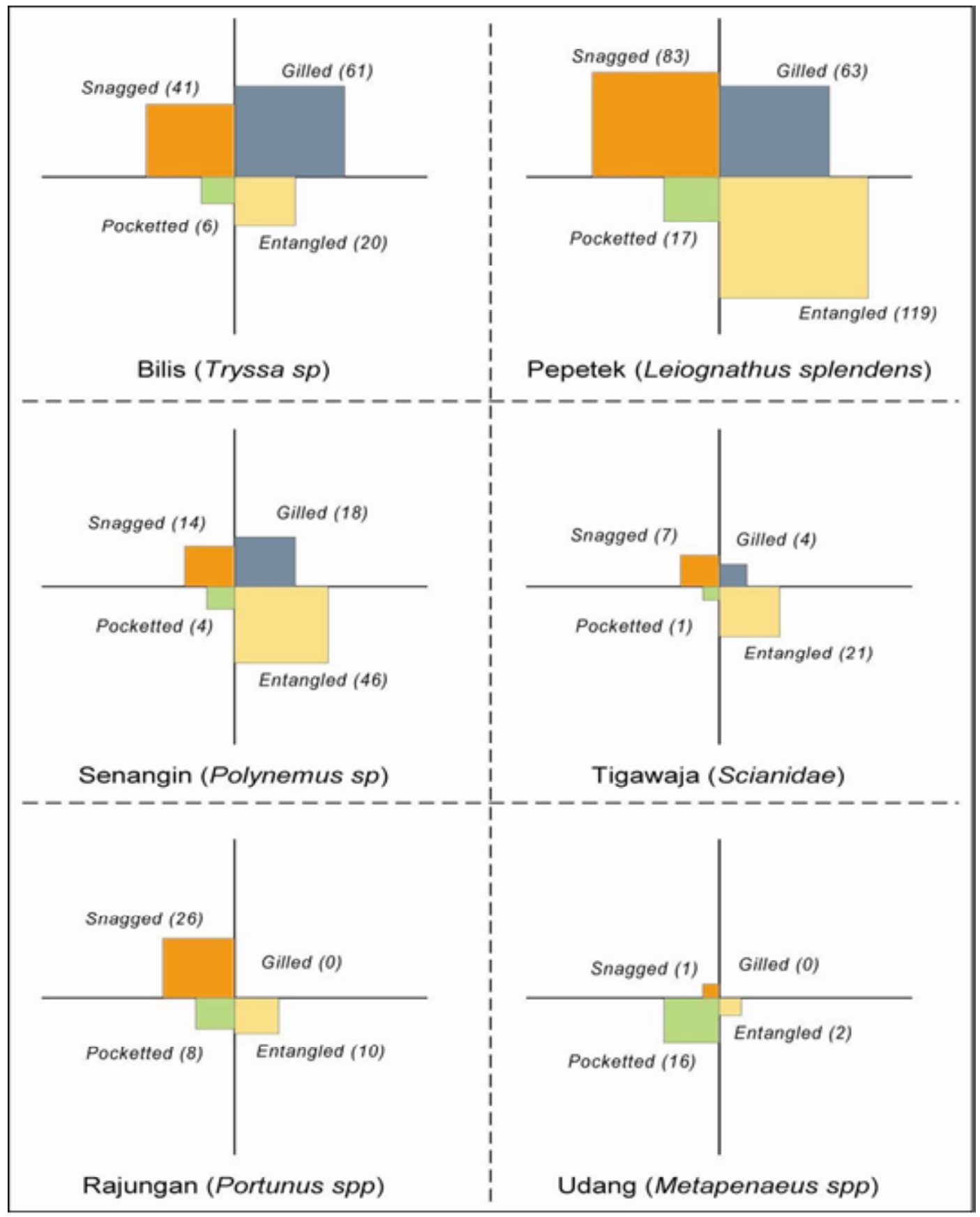

Gambar 3. Cara tertangkap beberapa tangkapan dominan oleh jatilap.

\section{KESIMPULAN}

1. Selama pengoperasian jatilap diperoleh tangkapan 22 jenis (502 ekor) dengan proporsi hasil tangkapan utama yaitu udang dogol 19 ekor $(3,8 \%)$, dan hasil tangkapan sampingan 483 ekor $(96,2 \%)$.

2. Komposisi ikan yang dominan tertangkap jatilap adalah ikan bilis $(25,5 \%)$, pepetek $(19,7 \%)$, dan senangin $(16,3 \%)$.
3. Jumlah total tangkapan jatilap jaring lapisan dalam 7,75 " adalah 259 ekor (51,59\%) dan jaring lapisan dalam 2,0" memperoleh tangkapan 243 ekor $(48,41 \%)$.

4. Ikan yang tertangkap dengan cara terpuntal (entangled) adalah paling dominan dibandingkan tertangkap dengan cara lainnya. Hal ini sesuai dengan sifat alat tangkap jatilap yang masuk dalam kategori tangle net (memuntal). 


\section{PERSANTUNAN}

Kegiatan dari hasil riset praktek lapangan Sekolah Pascasarjana Institut Pertanian Bogor, Program Studi Teknologi Kelautan, T.A. 2006-2007, di PascasarjanaInstitut Pertanian Bogor, Bogor.

\section{DAFTAR PUSTAKA}

Ayodhyoa, A. U. 1981. Metode Penangkapan Ikan. Penerbit Yayasan Dwi Sri. Bogor. 97 pp.

Mahiswara \& Wudianto. 1991. Uji coba jaring tiga lapis untuk menangkap udang karang (Spiny lobster, Panulirus spp.). Jurnal Penelitian Perikanan Laut. No.59 tahun 1991. Balai Penelitian Perikanan Laut. Jakarta. 83-91.

Pawarti, M. D. M. \& D. Nugroho. 1988. Laju tangkap, sebaran dan kelimpahan musiman ikan petek (Leiognathus splendens) di pantai utara Jawa. Jurnal Penelitian Perikanan Laut. No.46 tahun 1988. Balai Penelitian Perikanan Laut. Jakarta. 55-61.

Purbayanto, A., T. Arimoto, \& M. F. A. Sondita. 2000. Konservasi Keanekaragaman Hayati Laut Melalui Perbaikan Survival Ikan Non Target dan Hasil
Tangkapan Sampingan. Faculty of Fisheries and Marine Science. Bogor Agricultur University. Bogor. Indonesia and Departemen of Marine Siece Technologi. Tokyo University of Fisheries. Konan. Minato. Tokyo, Japan.

Purbayanto, A. 2006. Perikanan trammel net di Indonesia: Status kini dan prospek dan pengembangannya. Perikanan Trammel Net. Analisis Selektivitas dan Visiologi Tingkah Laku Ikan untuk Kepentingan Pengelolaannya. Departemen Pemanfaatan Sumber Daya Perikanan. Fakultas Perikanan dan Ilmu Kelautan. Institut Pertanian Bogor. Bogor. 1-13.

SEAFDEC. 1999. Regional Guidelenes for Responsible Fishing operations in Southeast Asia. Southeast Asian Fisheries Development Center. Thailand. $71 \mathrm{pp}$.

Sparre, P. \& S. C. Venema. 1992. Introduction to tropical fish stock assessment. Part 1. Anual 1. FAO Fisheries Technical Paper 306 (I): 1-337.

Subani, W. \& Barus H. R. 1989. Alat penangkap ikan dan udang laut di Indonesia. Jurnal Penelitian Perikanan Laut. No.50. tahun 1998/1999. Edisi Khusus. Balai Penelitian Perikanan Laut. Jakarta. $284 \mathrm{pp}$. 